Univerzitet u Beogradu, Filozofski fakultet Odeljenje za istoriju umetnosti, Beograd

DOI 10.5937/kultura1234104G UDK 75.071.1 Кле П.

\title{
NARATOLOGIJA PAULAKLEA
} VIZUELNO IZMEDU KNUZZENOSTT| |MUZKKE

Sažetak: Umetnost, kao i svoj teorijski rad i predavanja, Paul Kle je obogatio naratologijom u kojoj se vizuelno može analizirati u tesnoj vezi sa književnošć i muzikom. Kle je svoju naratologiju izražavao putem dnevnika i pisama, ali i u predavanjima, gde je specifične aspekte narativnog tražio u odnosu između tekstualnog i vizuelnog. Takođe, pisanjem, ali i čitanjem, on je gradio svoje sopstvo, istovremeno obogaćujući naraciju. U istraživanju i traženju što preciznije naracije koju će izraziti u adekvatnom obliku, Kle je posezao i za sredstvima koja su mu nudili književnost i muzika, jer su mu ove dve oblasti bile poznate $i$, u određenoj meri, vrlo bliske. Naime, Kle je $i$ sâm u ranoj mladosti svirao violinu, dosta čitao i iskazao talenat za pisanje, te je dvoumeći se između muzike i slikarstva kao životnog poziva, mogao slobodnije da se kreće između ove dve oblasti, tražeći u njima odgovarajući izraz za vizuelno. Ta vrsta kretanja slična je kretanju njegove linije, koja pronalazi adekvatne puteve da izrazi svoj slobodni, ali istovremeno precizni karakter.

Ključne reči: naratologija, književnost, muzika, vizuelno, tekstualno, Paul Kle

\section{Uvod}

Stvaralaštvo Paula Klea (Klee, 1879-1940), švajcarskog slikara, teoretičara umetnosti i naučnika, predstavlja veoma složen fenomen koji se prožima u više oblasti. Sudeći po bogatstvu knjiga iz Kleove kućne biblioteke, naslovima citiranim u dnevnicima i pismima, i narativnim situacijama na koje se upućuje u njegovim crtežima i slikama, književni ukusi ovog svestrano obrazovanog 


\section{GORAN GAVRIĆ}

stvaraoca bili su probrani, ali čvrsto ukorenjeni u kanon zapadne istorije književnosti. U sopstvenim radovima, Kle je tumačio niz narativnih žanrova, od epskih pesama do modernog romana, sa izrazitom sklonošću prema ironičnom. Polazeći od toga da se sva pričanja sastoje od onoga što je rečeno (priča ili sadržaj), i onoga kako je priča ispričana (diskurs ili forma), K. Porter Ejhel (Aichele) naglašava da „mada je on pridavao istu težinu ovim dvema komponentama, jedinstvenost vizuelnih priča leži najvećim delom u njegovim otkrićima, u domenu onoga što je on nazivao 'piktoralni diskurs"“'. Kleova pisanja se nisu uklapala u bilo koju šemu koju su razvili književni teoretičari. Čak i te slike, za koje se čini da su u skladu sa konvencijama neposredne slikovne ilustracije, idu uz, ili podrivaju, ove konvencije na različite načine. Kleova dva kompleta objavljenih knjiga ilustracija odgovaraju aspektima književnih pričanja, koje one vizuelno parafraziraju, ali njihovo slikovno prepričavanje je u oba slučaja bilo tako transformativno, da su slike, u stvari, predstavljale nove tekstove (slika 1).

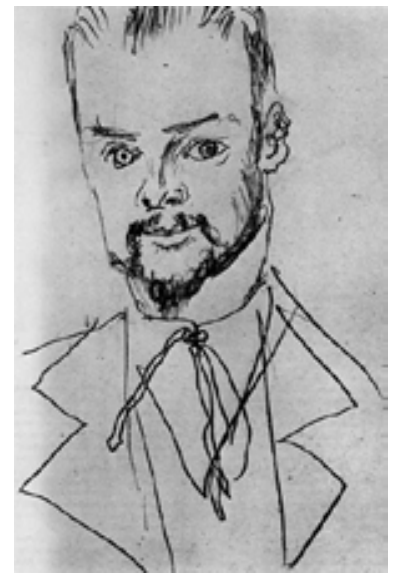

Slika 1: August Make, portret Paula Klea, crtež iz Tunisa, 1914.

Kleova serija slika pod nazivom „Opus I“ predstavlja početak njegove profesionalne prakse, dok serija „Pakleni park“ nagoveštava kraj te prakse. To su vizuelni tekstovi sa mnogo slika koji ne zavise ni od podražajnog odnosa između književnog i vizuelnog izlaganja za njihovo značenje, niti od hronološkog redosleda ili epizodnog kontinuiteta za njihovu

1 Aichele K. P., Paul Klee's Pictorial Writing, Cambridge University Press, Cambridge 2002, str. 18.; Porterova misli da "svaki napor da se okarakterišu Kleova složena vizuelna pričanja, mora početi sa priznanjem da on nije primenio nijednu narativnu formulu. Njegova knjiga ilustracija i druge vizuelne priče se razlikuju od 'antinaracija' Maksa Bekmana (Max Beckmann) i 'nepričanja' Baltusa (Balthus), koje je Džejms Elkins (James) naveo kao dokaz modernog pričanja u svojim početnim fazama samobrisanja.”, ibid., str. 18. 
strukturalnu koherenciju. Ove nelinearne vizuelne naracije dele najmanje jednu zajedničku karakteristiku sa knjigama koje sadrže Kleove ilustracije: one su dvostruko označene, bivaju i predstavljačke i diskurzivne, i tako izazivaju razlike između vizuelnih i verbalnih modela izražavanja. Bilo da ilustruju prateći tekst, ili su nezavisne od bilo kojeg književnog izvora, Kleova vizuelna pričanja su višeslojna, uvek obrađena u sopstvenom procesu proizvodnje. Kao takva, ona mogu biti čitana kao podtekstovi opširnije vizuelne priče koja je imala paralele u modernom ,procesu romana“.

S obzirom da su sva Kleova vizuelna pričanja višeslojna, bilo da ilustruju prateći tekst, ili su nezavisna od bilo kojeg književnog izvora, trebalo bi upravo taj princip razmotriti u kontekstu njegovih predavanja. Višeslojnost Kleovih vizuelnih pričanja je usko povezana sa procesom raslojavanja elemenata, koji su prikazani na njegovim slikama. Preciznost prisutna u ovom procesu može i te kako omogućiti konciznije sagledavanje višeslojnih vizuelnih pričanja. Kako se jedan elemenat procesom raslojavanja diferencira na veći broj različitih podelemenata, takav redosled u tumačenju neodoljivo podseća na deduktivni metod. Nasuprot njemu, višeslojnost je povezana sa induktivnim metodom jer se na svaki sloj dodaje sledeći, što je dovodi u vezu sa građenjem, koje Kle ističe kao ključno u procesu stvaranja umetničkog dela. Kao i u procesu raslojavanja, gde je važno otkriti osnovni elemenat od kojeg raslojavanje započinje, i kod višeslojnosti je veoma bitno utvrditi koji je to osnovni elemenat, na koji se pak u ovom slučaju ostali elementi nadograđuju.

\section{Lingvistički diskurs u Kleovim predavanjima}

Na značaj objedinjavanja teorije i prakse koje svoj uzor pronalaze u Kleovom primeru, ukazuje i njegova usredsređenost na ovaj proces posredstvom pisanja, koja počinju pismima, ${ }^{2}$ preko poetskih, pa sve do onih pedagoških, primenjivanih u njegovim predavanjima. Kao što je svako Kleovo delo stvarano na jednom nivou vizuelnog zapisa putem izvođenja, tako i svako njegovo predavanje sadrži u sebi obrazac tog istog zapisa, prevedenog u lingvistički diskurs. Takođe, bitno je ispitati i njegove radove koji se karakterišu narativnim modalitetom, zbog činjenice da je neophodno razjasniti odnos između jezika predavača i sadržaja, kako u njegovim radovima tako i u vizuelnim pričanjima koja

2 Džon Hajland (John Hyland) smatra da bismo "mogli pomisliti kako pismo, ako se stavi na određenu vizuelnu skalu, ili ako možda dobije poseban tipografski postupak, može po sebi da postane slika. U Kleovom radu, pisanje je često tamo u slici". Hyland J., An Extended Essay on the Use of the Gesture in Gertrude Stein's Tender Buttons and Paul Klee's Architecture Red-Green (yellow-purple gradations), Nebula, 2005, str. 123. 


\section{GORAN GAVRIĆ}

proizilaze iz tih radova. Poznato je da je Kle bio pod uticajem negovanja moderne lingvistike Ferdinanda de Sosira (Saussure), i da se bavio ovim koncepcijama u svojim slikama na različite načine. To se najbolje može videti ako se prouče Kleove beleške i radovi, kao i rane skice i crteži. ${ }^{3}$

Provoditi vreme posmatrajući/čitajući veliki broj njegovih slika znači postati uhvaćen (možda oslobođen) u vrsti verbalne slike, koja katkad može imati više osećaja za čitanje nego možda za gledanje. Po Kleu, slika je nesputavana oblast neprestanog kretanja, podsticanje oka da sakupi mnoštvo onoga što može biti viđeno u vezi sa onim što se vidi. Kao što Paul Baušac (Bauschatz) zapaža, „Kle je razumeo granice ljudske komunikacije. On je u svojim slikama računao sa ovim ograničenjima da bi stvorio vizuelne oblasti koje su, na neki način, komentarisale složenost ovih ograničenja“4. Ovo upućuje na Kleovo istraživanje haosa i reda, odnosno mogućnost da se, polazeći od beskonačnosti, dođe do određenih pravila i zakonitosti (slika 2). Elementi koje Kle predstavlja u svojim radovima su trajne stvari, ali uključivanjem u ikonički sadržaj one postaju promenljive, shodno njihovom preusmeravanju u stanje pokreta. Trajnost je ovde promenljiva kategorija, jer je uslovljena brojnim činiocima koji je diferenciraju na više različitih elemenata. Kretanje na slici postaje konstantna kategorija, jer je interaktivni odnos između različitih elemenata prisutan u svakom segmentu slike. Na izvestan način, jedan segment Kleove slike, na kojem se odvija kretanje, može uticati na to da čitava slika odaje utisak pomeranja njenih elemenata, posredstvom kretanja iz jednog položaja u drugi.

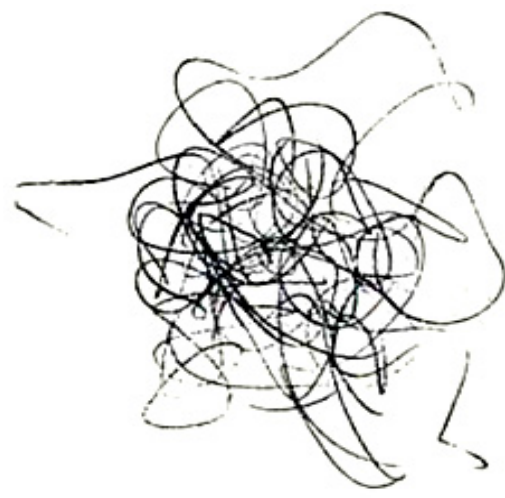

Slika 2: Haotično, iz knjige Paula Klea

„Zapisi o umetnosti“, skica s predavanja, 1998.

3 Paul Baušac, takođe, u svom članku ukazuje na Kleovu upotrebu jezika u slici, da je "mnogo Kleovog raspravljanja jasno, ne analogijski, i da lingvistički principi igraju centralnu ulogu u njegovom umetničkom poduhvatu". Bauschatz P., Paul Klee's Speaking Pictures, Word and Image, vol. 7, No. 2, 1991, str. 149-163.

4 Ibid., 162. 


\section{GORAN GAVRIĆ}

Kle je uključivao različite lingvističke elemente: blisku distancu i percepciju različitih komponenti značenja. On je postupao prema „pisanju slike“ koje se krije iza opisa predmeta. ${ }^{5}$ Kle je na svojim predavanjima ustanovio odličan metod, jer je $u$ isto vreme na tabli prikazivao i skice $i$ tekst, čime je svaki student $u$ istom momentu percipirao i vizuelno i lingvističko. Na osnovu ovog Kleovog metoda predavanja kao odličnog primera, mogli bi da se sačine metodi koji prate takvu liniju razvoja. U vezi s tim, vidim sledeće mogućnosti: s obzirom da je koegzistencija delova tekstualnog segmenta na slici sa vizuelnim sadržajem moguća samo u celovitosti ikoničkog sadržaja, proces uključivanja slova u tekstualni segment ne može ipak biti preslikan u vizuelnu sferu. Tako je objektivizacija smisla vizuelnog sadržaja realna, dok poimanje slova u sklopu tekstualnog sadržaja mora biti subjektivno, ako tražimo smisao tekstualnog u vizuelnom. Tekstualni sadržaj možemo percipirati kao deo vizuelnog sadržaja ako ga uključimo kao jedan od segmenata ikoničkog sadržaja u celovitost slike. Ono što bi kao sledeći korak moralo da se učini je preusmeravanje objektivnog poimanja tekstualnog sadržaja u pravcu subjektivnog i inventivnog kombinovanja. Pritom percepcija tekstualnog sadržaja, u opštem poimanju vremena, predstavlja vremenski obrazac koji je istovetan percepciji vizuelnog sadržaja.

Isto tako, u mnogim oblastima, pa tako i u pisanju, kao sredstvo realizacije koristi se ruka, odnosno šaka. Ona se i tokom procesa pisanja pomera u saglasnosti sa svešću. Razlika je samo u tome što je kod crtanja veoma bitna preciznost u usaglašavanju svesti i šake, dok kod pisanja to nije od značaja, jer većina ljudi piše i pritom ne obraća svesno pažnju na taj čin. Kao što umetnik na početku zamisli jedno, a na kraju ispadne drugo, nešto slično se dešava i piscu, koji ipak ima veću kontrolu jer raspolaže već utvrđenim terminima i dovoljnim fondom reči. Ali to ne znači da se i piscu - kao što je to slučaj i sa umetnikom - ne može dogoditi da se zbog stalnog protoka ideja ne može iskristalisati adekvatna i prečišćena ideja. Ovo za likovnog umetnika može predstavljati dodatni problem kada nastoji da usaglasi rad šake sa svešću, dok kod pisanja to nije neophodan faktor koji može poremetiti čitav proces.

5 Marselin Plejne (Marcelin Pleynet) beleži u svojoj studiji o Matisu (Matisse): "Pravo pitanje je znati šta je umetnik uradio sa onim što je video; da li je ono što je video odredilo ono što je stvorio, i da li ono što je stvorio u nekoj meri nije odredilo ono što je on bio sposoban da vidi." Pleynet M., Henry Matisse, Gallimard, 1993, str. 152. 


\section{GORAN GAVRIĆ}

\section{Kleovi dnevnici kao izvor naracije}

Postoje brojni primeri da se ozbiljnom posvećenošću pisanju sopstvo može obrazovati, ali i korigovati. Jedan od takvih primera je zasigurno Kleov, koji je sa svojim dnevnicima pokazao da je moguće obrazovati i korigovati sopstvo ako se ide ovim putem. Kod Klea, proces pisanja koji realizuje putem dnevnika u direktnoj je vezi sa procesom crtanja i slikanja. Jer njegovi dnevnici su neka vrsta autobiografije, odnosno pisanja života, a po Kleu, proces stvaranja se ogleda u kretanju kroz život. On dakle o životu koji živi ujedno i piše, beleži ga na papiru, smešta ga na dvodimenzionalnu površinu, u svesku koju je moguće obuhvatiti rukama. U dnevnicima je pokušavao da sebe konstituiše na drugačiji način, što znači da, iako je u njima pisao o životu, on je težio da neke stvari izmeni, koriguje sopstvo. Kle ne samo da je u dnevnicima korigovao sopstvo, već ga je i kritikovao. Taj kritički stav je uticao na to da Kle u dnevnicima zapisuje samo ono što na neki način ima značaja u odnosu na sopstvo i njegovo uobličavanje.

Vizuelno otkriva i ono podsvesno što umetnik nikada ne izražava svojim ratiom. Iz tog ugla opažanja moglo bi se reći da, iako naizgled završeno, umetničko delo neprestano podleže dubinskoj analizi ispod površine dela. U Kleovom dnevniku, između delova teksta, pojavljuju se skice i crteži; on pojedine misli želi da izrazi vizuelnim. Dakle, vizuelno pojednostavljuje tekstualno i otkriva ono što je u tekstu skriveno; kada je delo završeno, ono podleže kritici i kompleksnoj analizi. Umetnikova misao u dnevniku menja se kako on sazreva, i kako se u njegovom životu dešavaju promene. Da li to znači da dnevnik sadrži više detalja vezanih za misli koje grade idejni proces? Moglo bi se reći da je to skup neodređenih ideja koje egzistiraju u neprekidnom procesu, što će reći da delo sadrži ideje prikupljene od momenta njegovog nastajanja do sklapanja u jednu organizovanu celinu. Ono što je umetnik želeo da kaže rekao je, a ono što će tek poželeti da izrazi, moći će to da učini u sledećem umetničkom delu, ali ne u već završenom. Dakle, dnevnik se može definisati i kao skup različitih dela, koja nedovršena egzistiraju u kompleksnom skupu ideja. S druge strane, u dnevniku se pominju putovanja i doživljaji koji su se snažno urezali u Kleovo pamćenje. Ovde je ključna kategorija promenljivosti; promena prostora $\mathrm{u}$ realnom životu prouzrokuje drugačiji tok misli u samom dnevniku, što dalje može uticati i na proces stvaranja umetničkog dela. Prostor ne mora da bude faktor koji utiče na promenu, već samo nepromenljiva kategorija koja prouzrokuje

promenu doživljaja. 


\section{GORAN GAVRIĆ}

Ipak, Kle ne piše dnevnik u klasičnoj formi koja predstavlja situacije što se dešavaju u svakodnevnom životu; one se pojavljuju na momente, samo kao nagoveštaji dubljeg građenja, ne dopuštaju mu da se u potpunosti odvoji od stvarnosti. S druge strane, taj kontrast postaje izvorište kompleksne i kreativnije analize. Kada Kle u dnevniku piše o procesu nastajanja jedne grafike, asocijacija može da bude u nekom elementu iz stvarnosti; cinkana ploča se premazuje asfaltom koji je crn (noć), povlačenjem linija nastaju beli elementi (svetlost). Dakle, kontrast, uslov bez koga ne može da se odigra proces nastajanja i strukturalnog građenja, i ovde je prisutan. U dnevniku uobičajeni realni elementi, ovde se inkorporiraju u metafizički sadržaj; realni elemenat, uzet iz svakodnevnog života, postaje izražajno sredstvo za predstavljanje realnog procesa.

U Kleovom dnevniku misao započinje građenje umetničkog dela; u njemu postoji veća sloboda i proces nastajanja je spontaniji nego u umetničkom delu. Delo podleže umetničkoj kritici i sadrži pored slobode, zakonitosti i norme. Iako je pri pisanju dnevnika Kle još slobodniji i spontaniji nego pri stvaranju umetničkog dela, u pojedinim trenucima njegova odgovornost prema istorijski i društveno ustanovljenom umetničkom načinu izražavanja izbija u prvi plan. Ali upravo ta neuobličena slika može nam pružiti najprecizniji odgovor za njegovu umetnost; neke misli koje je Kle izrazio u dnevniku, možda se nikada nisu ugradile ni u jedno njegovo umetničko delo.

Proces nastajanja jedne grafike, kao realan, preoblikuje se $\mathrm{u}$ oponenta klasičnog dnevničkog prikaza stvarnosti. S druge strane, taj proces je nemoguće vizuelno prikazati u dnevniku, jer to ne dozvoljavaju forma sadržaja, prostor i vreme. Zato se vizuelno (crtež, skica) i javlja između tekstova, kako bi premostilo razliku koja je prisutna usled stvaranja dijametralno suprotnih formi izražavanja. Ono nagoveštava sam proces građenja, ali ne može da ga prikaže u potpunosti jer je ograničeno vremenom i prostorom. Kle, međutim, proces stvaranja i pravljenja jedne grafike u dnevniku ne prikazuje kao događaj iz svog života, već kao postupak izrade koji čitalac koga to zanima treba da usvoji. Dakle, opet dolazimo do pravila i normi, koji su izgleda u Kleovom slučaju neizbežni, čak i u dnevniku, što ne znači da nije moguć i slobodniji vid prikaza.

Misli koje je Kle iskazao u dnevniku, delovi su jednog dugog procesa, ali i oponenti vizuelnog načina prikazivanja nekog umetničkog dela. Kle u svojim dnevnicima konstruiše, kritikuje i koriguje sopstvo, i na kraju stilizuje kad ih prečišćava. On u njima zapisuje samo ono što, na neki način, ima značaja $u$ odnosu na sopstvo i njegovo uobličenje. On nas u njima obaveštava o prostoru u kojem se kreće, o vremenu koje struktuira 


\section{GORAN GAVRIĆ}

njegov život, o vezama koje ono uspostavlja. Retrospektivnost, aktualnost i prospektivnost - tri su aspekta koji pri tome dolaze do izražaja: on reflektuje doživljeni život i deli ga na različite stadijume kako bi očuvao i pronašao objašnjenja o svojoj vlastitoj aktualnosti, njenom naročitom izazovu. $\mathrm{Na}$ ovaj se način, prospektivno, budući život, sa kojim se nikada neće pomiriti zato što je sadašnji, prestruktuira, i ne miri se s tim da se mora prikloniti izboru. Pažnju nikad ne smemo zadržavati na onome što je stvarno, već na onome što je mogućno: tako se proizvodi realnost. Nikada se ne zadovoljiti stvarnim jer ništa nije prolazno.

Iskazom da je „sliku Dorijana Greja još juče odbacio, dok mu ona sada pričinjava zadovoljstvo, a prekjuče bi ga baš opila"6, Kle potvrđuje istinu koja se ogleda u kategoriji promenljivosti. U dnevnicima, Kle sebi postavlja ciljeve prema kojima teži, vrši, kako on to izričito imenuje, "izbor", stavljajući time u pogon jednu ličnu teologiju koja izmiče izboru na koji ga život primorava. Kle ovaj postupak određuje kao praksu života i umetnosti: „Postavi sebi ciljeve: igraj se, obmanjuj sebe i druge, budi umetnik ${ }^{67}$. To moraju biti ciljevi, koji za mnoge druge nisu ciljevi. Ali on je svestan da je put ka iskupljivanju jednog projektovanog cilja popločan radom: „Put će biti dugačak, rad nežnih udova složen“"8. On se nada da će stvarati lepotu, ali on smera na lepotu koja se ne može pouzdano razlikovati od ružnoće, da se o značenju njegovih figura mogu napisati disertacije. Obećanje koje daje važi za njegov rad - on ga daje sebi samome i prijateljima; i pred njima i pred samim sobom oseća krivicu, a katkad ni pred kim. U dnevnicima se on takođe pita o svome sopstvenom životu, da li je on zapravo u saglasnosti sa ciljevima koje je sebi postavio i da li se nalazi na pravom putu. To je polaganje računa o proživljenom životu, koji je u antici bio poznat kao logon didonai. ${ }^{9}$ Ovaj postupak gradi osnovu da

6 Klee F. (ed.), The Diaries of Paul Klee, 1898-1918, University of California Press, Berkeley 1968, str. 187.

7 Klee P., Tagebücher, Dumont, Keln 1957.

8 Ibid., „Put je veza prirodnih objekata, njihova beskonačna konačnost“, kaže Heraklit, a Šiler (Schiler): „Putovanje je počelo, put je završen“, dok Hegel misli da je ,početak isto što i kraj“. Ukoliko se, uz pomoć Heraklita, ono između početka i kraja shvati kao put, onda je put taj logos po kojem početak i kraj jesu početak i kraj. Vidi Windelband W., Povijest filozofije, preveli Nada Šašel, Danko Grlić i Danilo Pejović, knjiga prva i knjiga druga, Naprijed, Zagreb 1990.

9 Sintagma logon didonai može se prevesti na više načina, pri čemu svi ti prevodi upućuju na epistemološki aspekat tog izraza, počevši od konkretnog prevoda sa "položiti račun" preko prevoda tog izraza sa "potkrepiti", "opravdati” do nešto neutralnijeg prevoda sa "objasniti” koji više odgovara naučnom mišljenju i diskutovanju. Deretić I., Uloga logosa u Platonovom određenju znanja, Arhe, br. V, 9, Novi Sad 2008, str. 92. 


\section{GORAN GAVRIĆ}

sopstveni život dobije „stil“", ukoreni i iznova obnovi. Život se pritom pokazuje kao predmet estetike, ali i predmet opažanja i stvaranja. Pritom je reč o proširenju polja estetike umetnosti na umetnost života.

\section{Otkrića iz „Opusa I“ u kontekstu muzike}

Kle je ubedljivo predstavio seriju svojih Otkrića kao kohezivan „Opus I“. Termin „opus“, često primenjivan na muzičke kompozicije, i povremeno na književna dela, bio je naročiti izbor za relativno skromnu grupu od 11 vizuelnih slika. ${ }^{10} \mathrm{U}$ vezi sa tim Ejhel kaže: „Najjednostavnije objašnjenje za Kleov izbor terminologije je očigledna paralela između njegovih brojnih Otkrića i numeričkog sistema korišćenog u katalogizaciji muzike. Samim tim može se ustanoviti da je, prisvajajući termin tradicionalno rezervisan za muziku i književnost, Kle nameravao da izgradi konceptualni okvir u kojem su različite slike mogle da budu čitane kao sastavni delovi vizuelne celine, koja je doživljena i razumevana tokom vremena" ${ }^{\text {"11. }}$ U pogledu manipulacije, muzika može da ostvari rezultate koji su van domašaja slike. S druge strane, slika je ispred muzike u nekoliko pojedinosti. Muzici je, npr., na raspolaganju vreme trajanja, dok slika može da predstavi posmatraču celi sadržaj svoje poruke u jednom trenutku. Muzici, koja je spolja oslobođena pomoću prirode, ne treba određena forma za njeno izražavanje, dok se slikarstvo zanima za reprodukovanje prirodnih formi i fenomena.

S obzirom na to da je Kle bio slikar koji nije nalazio zadovoljstvo u pukom predstavljanju - koje je ipak umetničko - on je, samim tim, čeznuo da izrazi svoj unutrašnji život. Kle je zavideo na lakoći sa kojom muzika, najnematerijalnija i najapstraktnija od svih umetnosti, ostvaruje ciljeve koji nisu dostupni likovnoj umetnosti. On je zasigurno pokušavao da primeni metode muzike na svoju sopstvenu umetnost: ritam u slici,

10 Učenje o brojevima ima dugu istoriju, ono se vremenom i menjalo: u početku, brojevi su identifikovani sa stvarima, potom sa principima stvari i njihovog kretanja, a kasnije su tumačeni kao strukture, spoj ograničenog i neograničenog (Filolaj); upravo zato su pitagorejci sintezu ograničenog i neograničenog videli u harmoniji, pa muzika nije izraz samo nekog nastajanja (u smislu kretanja svega) već brojčano nastajanje, i njena suština nije ni u čem drugom, do u numeričkom nastajanju oblikovanog predmeta, pre svega, kosmosa $\mathrm{u}$ celini, a potom i svih stvari u njemu. Лосев А. Ф., Античная музыкальная эстетика. - M., 1960, str. 31., nav. prema: Uzelac M., Filozofija muzike, Stylos, Novi Sad 2005, str. 36.

11 Aichele K. P., Paul Klee's Pictorial Writing, Cambridge University Press, Cambridge 2002, str. 18. 
GORAN GAVRIĆ

matematičko i apstraktno građenje, ponavljanje melodija boja, stavljanje boje u pokret. ${ }^{12}$

\section{„Čitanje“ Kleovih grafika}

Među mnogim mogućim gotičkim uzorima za figure u Dva gospodina se klanjaju jedan drugom, svaki pretpostavlja da je drugi na višem položaju (1904) su skeletni partneri u kasnim srednjovekovnim predstavljanjima Igre i smrti (slika 3). Razmatrajući ovu sliku, kao i celu grupu od 11 Otkrića, Ejhel kaže sledeće: „Pored toga što obezbeđuje ključ opsega izvora za Otkrića, Kleov gotičko-klasični polaritet poziva posmatrača da razmotri grupu od 11 Otkrića kao inicijalnu manifestaciju uzajamnog dejstva polarnih suprotnosti, koje bi mogle da nastave

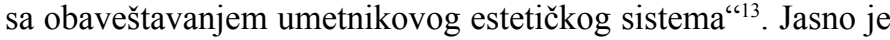
da je Kle bio pod uticajem gotičkog stila, i da su njegove figure poprimile nešto od tog stila. Međutim, osnovni uzrok Kleove potrebe za izduživanjem figura vidim u nečem drugom.

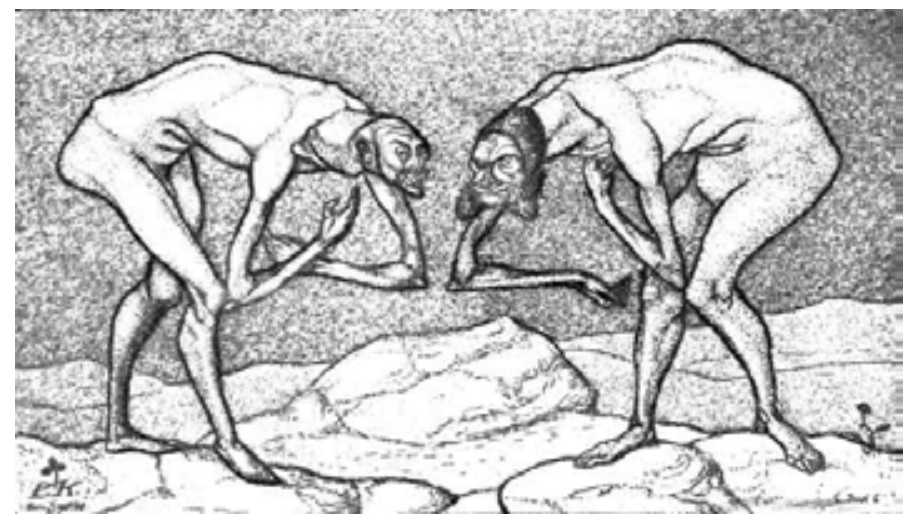

Slika 3: Paul Kle, Dva gospodina se klanjaju jedan drugom, svaki misli da je drugi na višem položaju (Otkrića 6), bakropis, Solomon R. Guggenheim Museum, New York 1903/5.

12 Obrazloženje Marvina Minskog (Minsky), da su procesi koordinacije pokretača misli u našem razumevanju prostora i muzike veoma slični, ilustrovano je u sledećem poređenju: "Kako i muzika i vid grade stvari u našim umovima? (...) Čuti temu je kao videti stvar u sobi, odeljak ili kretanje je kao soba, i cela sonata je kao čitavo građenje. Ja ne mislim da kažem, kako muzika gradi vrste stvari koje čini graditelj prostora (To je suviše naivno poređenje zvuka i mesta). Ja ne mislim da kažem kako kompozitori stimulišu koherenciju, pomoću uključivanja istih vrsta koordinacija pokretača misli, koje vid koristi da proizvede svoju iluziju stabilnog sveta korišćenja, naravno, različitih pokretača". Ne postoji ništa zajedničko između ove dve teorije, osim generalne početne tačke prisnih veza između prostora i vremena. Koncept "prostor-vreme", na kraju veka je radikalno drugačiji od svojih početaka. Minsky M., Music Mind and Meaning, in: Machine Models of Music, eds. Schwanauer S. M. i Levitt D. A., Massachusetts Institute of Technology, Massachusetts 1993, str. 342.

13 Aichele K. P., op. cit., str. 19. 
Naime Kle je pronalazio samo oblike koji bi na drugim planetama mogli da budu isti takvi. U skladu sa tim, a uz to i analizirajući njegove otiske iz „Opusa I“ Otkrića i druge njegove radove, pretpostavljamo da je Kle na početku imao ideju da i figure budu homogene sa tim oblicima, odnosno da se sastoje od njih. Njegove figure nisu poznate ljudskom rodu, one kao da zaista potiču sa neke druge planete. Reklo bi se i da je Kle iskoristio elemente gotičkog stila samo kao sredstvo za postizanje višeg cilja, za stvaranje različitih elemenata u procesu Geneze. Stoga možemo zaključiti da su Kleu upravo te druge planete poslužile za stvaranje bića nalik ljudskim, ali samo u meri u kojoj mi želimo da opazimo osnovne elemente, što čine i celinu ljudskog tela; kada je reč o veličinama i dimenzijama delova tela Kleovih figura, one se dosta razlikuju od nama poznatih.

Poslednji bakropis iz Kleove serije Otkrića, Zreli Feniks (1905) ${ }^{14}$ predstavlja uobličavanje formi na sličan način kao u prethodnom bakropisu, s tim što je figura sada sasvim izdignuta i ponosito stoji uspravljena, sa kopljem na čijem vrhu se nalazi lobanja mrtvog Feniksa (slika 4). Kle je svojoj ženi Lili (Lily) objasnio ovaj otisak na sledeći način: „Ja imam alegoriju nepodesnosti kao što je buđenje Feniksa; piktoralno veoma interesantnu. Na primer, ti upravo moraš da zamisliš da je tamo baš bila revolucija, nepodesnost je spaljena, i sada je tu, podmlađen, raste iz svog pepela. To je ono u šta ja verujem..." ${ }^{15}$ Međutim, Suzana Parč (Susana Partsch) govori o tome kako je Kle izmenio tumačenje nakon što je završio sliku: „Podmlađeni Feniks je postao zreo i (kao i sva Inventionen ${ }^{16}$ ) praćen objašnjenjem: Zreli Feniks kao simbol nepodesnosti ljudskih stvari - čak i najviše - u vreme krize“"17. Neka tumačenja u vezi ovog otiska, povezuju Kleova razmišljanja o njemu sa nemačkim pobedničkim mentalitetom i Prvim svetskim ratom. Ovo drugo je povezano sa tim da je on očekivao brzu pobedu Nemaca, i nadao se da će nacionalni uspon ponovo doneti Nemcima sredstva (hrabrost i novac od pokrovitelja i izdavača), koja su poslednjih godina bila uskraćena. Kle je ipak nakon pogibije svog prijatelja, nemačkog

14 Paul Kle o ovoj grafici u svojim “Dnevnicima” piše: “Zreli Feniks ne predstavlja idealnu figuru; on je stvarno 500 godina star, i kao što se vidi, sve vrste stvari su mu se desile za to vreme. Ovo ukrštanje između realizma i bajke je ono, što proizvodi komičan efekat. Njegov izraz nije bez tragične strane, i misao koja će uskoro ovo stvorenje redukovati na partenogenezu, ne otvara bilo kakve ohrabrujuće perspektive. Ritam neuspeha, sa periodičnošću od 500 godina, uzvišeno je komična predstava”. Klee F., The Diaries of Paul Klee, 1898-1918., University of California Press, Berkeley 1968, str. 168.

15 Partch S., Paul Klee, 1879-1940, Taschen, 2003, str. 31.

16 Nemačka reč za Otkrića.

17 Ibid., str. 31-32. 
slikara Augusta Makea (Macke), u ratu, promenio svoj stav u odnosu na ovaj problem.

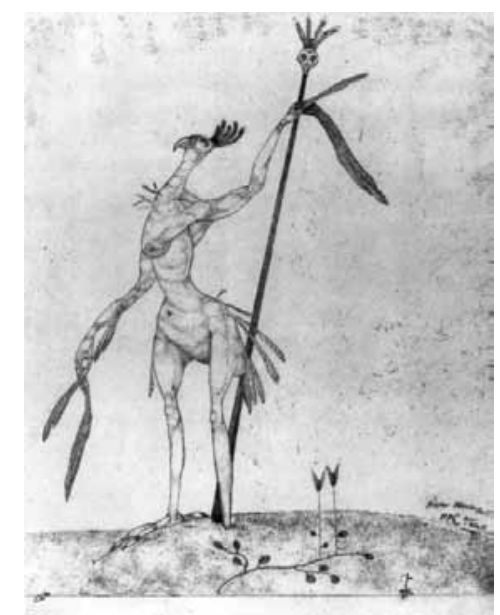

Slika 4: Paul Kle, Zreli Feniks (Otkrića 9), bakropis, San Francisco MOMA, 1905.

Ipak, tumačenje ćemo preusmeriti u drugom pravcu, koji nema mnogo veze sa ranijim tumačenjima, već pre sa celokupnom idejom na kojoj počiva serija Otkrića, naročito sa prethodnim bakropisom iz iste serije, Dva gospodina se klanjaju jedan drugom... Naime, dok pravimo paralelu između ova dva bakropisa, ne možemo a da ne primetimo da razlika - između figura koje se klanjaju na jednom bakropisu, i figure koja stoji uspravljena, na drugom - ukazuje na Kleovu dvosmislenost i nepodudaranje sa onom pričom o nemačkom pobedničkom mentalitetu. Iako je sasvim opravdano da tumačenje može, i treba da se zasniva i na stvaranju umetnika koji je pod utiscima i uticajima događaja iz svog života, među kojima su i oni revolucionarnog karaktera što su uticali i na širu svetsku populaciju, smatram da u ovom slučaju Kleova ideja nije zasnovana u dovoljno jakoj meri na tumačenjima tog tipa. Takav zaključak ćemo izvesti i na osnovu toga što je i u ostalim radovima iz serije Otkrića, ideja vodilja zasnovana na načelima koja prate evolutivni razvoj, proizašao iz najvišeg čina stvaranja - Geneze.

\section{Zaključak}

U pisanju Kle skicira jedan koncept svoga života; njegov život je jedan projekat za koji se on nada da će ga realizovati i sve svoje napore usmerava ka tome. Pitanje koji su razlozi za to, on ne razlaže naširoko: „Zašto? Bez naslućivanja“"18. Proširenje njegovog sopstva mu je toliko važno da će reći: „Ja jedva pomišljam

18 Klee P., Tagebücher, Dumont, Keln 1957. 


\section{GORAN GAVRIĆ}

na likovnu umetnost, ja ću raditi jedino za gospodina $O s o b u$. Pritom moram biti konsekventan" ${ }^{19}$, i nada se da će iz svega toga proizaći izraz u likovnim umetnostima. On rano govori o ,uznošenju sopstva“ i jednoj „novoj etici“ koja ga opseda i jedno ranije, po sebi beznačajno, iskustvo dovodi do toga da na put, ako do njega dođe, sam krene. Pritom za stil njegove egzistencije, upravljanje sopstvenim životom, postoje „Glavni i sporedni put" - tako on takođe naziva jednu sliku koju je naslikao 1929. godine i sastoji se iz bojenih površina - koji su međusobno povezani. Iz glavnog puta stalno proizvoljno vode sporedni putevi i odatle dalje produžavaju ili se vraćaju na glavni put; takođe, sa sporednog puta se može izaći na glavni put. Svakako, u ovom lavirintu se može takođe zalutati ili izgubiti, ili pak očarati estetikom boje i nijansirane kompozicije; glavni put se otvara kroz izvestan kontinuitet vođenja linije.

Kao i svaki drugi umetnik, i Kle je na samom početku stvaranja - kada se još razvija ideja - pravio skice kako bi na kraju dobio najbolje rešenje. Međutim, ono što je posebno karakteristično za Klea je to da je on na svojim predavanjima između tekstualnog dela koristio i skice. Ovo upućuje na to, da je njemu ideja bila važnija od završenog dela, barem što se njegovih predavanja tiče. Tako se pokazuje da Kleova predavanja ne samo da su bila važna, iz razloga što je on njima prenosio veoma bitno znanje svojim studentima (što je bio i osnovni cilj), već su ona sadržala $\mathrm{u}$ sebi obrazac njegove umetnosti i ukazivala na postupnost $\mathrm{u}$ procesu stvaranja umetničkog dela. O postupnosti naročito govori sinteza tekstualnog i vizuelnog u njegovim predavanjima, a vizuelno, odnosno skice, ističu značaj početne ideje za dalje građenje. Ujedno, kada se ta početna ideja ustanovi, onda je dalji rad utemeljeniji i izvesniji.

\section{LITERATURA:}

Aichele K. P., Paul Klee's Pictorial Writing, Cambridge University Press, Cambridge 2002.

Barthes R., The Responsibility of Forms: Critical Essays on Music, Art, and Representation, Is Painting a Language?, University of California Press, Berkeley and Los Angeles 1991.

Bauschatz P., Paul Klee's Speaking Pictures, Word and Image, vol. 7, No. 2, 1991.

Deretić I., Uloga logosa u Platonovom određenju znanja, Arhe, br. V, 9, Novi Sad 2008.

Harris Y., From Moving Image to Moving Architecture, Cambridge England, Cambridge 2000.

19 Ibid. 


\title{
GORAN GAVRIĆ
}

Hyland J., An Extended Essay on the Use of the Gesture in Gertrude Stein's Tender Buttons and Paul Klee's Architecture Red-Green (yellow-purple gradations), Nebula, 2005.

Klee F., The Diaries of Paul Klee, 1898-1918, University of California Press, Berkeley 1968.

Klee P., Tagebücher, Dumont, Keln 1957.

Minsky M., Music Mind and Meaning, in: Machine Models of Music, eds. Schwanauer S. M. i Levitt D. A., Massachusetts Institute of Technology, Massachusetts 1993.

Partch S., Paul Klee, 1879-1940, Taschen, 2003.

Pleynet M., Henry Matisse, Gallimard, 1993.

Uzelac M., Filozofija muzike, Stylos, Novi Sad 2005.

Windelband W., Povijest filozofije, preveli Nada Šašel, Danko Grlić i Danilo Pejović, knjiga prva i knjiga druga, Naprijed, Zagreb 1990.

\author{
Goran Gavrić \\ University of Belgrade, Faculty of Philosophy - \\ Art History Department, Belgrade \\ NARRATOLOGY OF PAUL KLEE \\ THE VISUAL BETWEEN LITERATURE AND MUSIC
}

\begin{abstract}
Paul Klee, had enriched his theoretical work and lectures with narratology in which the visual can be analyzed in close relation to literature and music. Klee expressed his narratology not only in his diaries and letters but also in his lectures where the specific aspects of the narrative where sought in between the textual and the visual. He built the narration by writing as well as reading, at the same time building his own self. In searching and seeking a narration that would be as precise as possible and expressed in adequate form, Klee reached for means offered by literature and music as the two fields that were familiar, and even to some degree, very close to him. As a matter of fact, Klee played the violin in his youth, read extensively and expressed a talent for writing, and being ambivalently inclined to both music and painting as his life calling, he could move between these two field freely, seeking in both of them expression of the visual. This movement resembles the movement of his lines which find adequate paths toward expression of his simultaneously liberated and precise nature.
\end{abstract}

Key words: narratology, literature, music, visual, textual, Paul Klee 